\title{
Phenotypic and genotypic characterization of lactobacilli from Churpi cheese
}

\author{
Prashant ${ }^{1}$, Sudhir Kumar Tomar ${ }^{2}$, Rameshwar SingH ${ }^{2}$, \\ Subhash Chandra GuPTA ${ }^{1}$, Dilip K. ArORA ${ }^{3}$, Balwindar Kumar Joshi ${ }^{1}$, \\ Dinesh KuMAR ${ }^{1 *}$ \\ ${ }^{1}$ Genes and Genetic Resources Molecular Analysis Lab, National Bureau of Animal Genetic Resources, \\ Karnal, Haryana 132001, India \\ 2 Dairy Microbiology Division, National Dairy Research Institute, Karnal, Haryana 132001, India \\ ${ }^{3}$ National Bureau of Agriculturally Important Microorganisms, Kusmaur, Mau Nath Bhanjan, \\ Uttar Pradesh 275101, India
}

Received 8 January 2009 - Revised 20 May 2009 - Accepted 10 June 2009

Published online 25 July 2009

\begin{abstract}
The aim of this study was to investigate the diversity of lactobacilli in Churpi cheese, a traditional variety of cheese made from yak milk. Thirty-five lactobacilli isolated from five different samples procured from different parts of Arunachal Pradesh (India) were analyzed by phenotypic and genotypic methods. The $16 \mathrm{~S}$ rDNA sequencing for all the isolates was performed. Five different species of lactobacilli were isolated from Churpi cheese with the predominance of Lactobacillus paracasei followed by Lactobacillus plantarum. All the isolates were further evaluated for their technological properties such as citrate utilization, exopolysaccharide (EPS), bacteriocin, and acid production. Forty-three percent isolates were found positive for citrate utilization, while 14\% were found good acid producer, and $11 \%$ for EPS production. Lactobacillus coryniformis was an uncommon species found in Churpi cheese. Isolates obtained in this study can be potentially used for the development of defined strain starter for Churpi cheese.
\end{abstract}

Churpi cheese / Lactobacillus / 16S rDNA / yak

摘要 - Churpi 干酪中乳杆菌的表型和遗传型特性分析。本研究目的是调查 由牦牛乳 制作的传统干酪—Churpi 干酪中乳杆菌的多样性。本研究选取了来自印度 Arunachal Pradesh 不同地区的 5 种不同的 Churpi 干酪样品, 通过表型和遗传型方法分析, 从中 共获得了 35 株乳杆菌。所有分离菌株均进行了 $16 \mathrm{~S}$ rDNA 序列分析。从 Churpi 干酪 中获得了 5 种不同的乳杆菌, 其中 Lactobacillus paracasei 为优势菌, 其次是 Lactobacillus plantarum。对所有分离的菌株的技术特性, 如柠檬酸盐利用能力、产胞外多糖、细菌素 的能力和产酸能力等进行了进一步评价。 $43 \%$ 菌株能够利用柠檬酸盐, $14 \%$ 的菌株具有 较好的产酸性能, $11 \%$ 的菌株可产胞外多糖。Lactobacillus coryniformis 是 Churpi 干 酪中罕见的菌种。当前研究所获得的菌株, 具有用于生产 Churpi 干酪发酵剂的潜力。

\section{Churpi 干酪 / Lactobacillus / 16S rDNA / 牦牛}

Résumé - Caractérisation phénotypique et génotypique de lactobacilles de fromage Churpi. Le but de cette étude était d'évaluer la diversité des lactobacilles du fromage Churpi, une variété

*Corresponding author (通讯作者): dineshkumarbhu@gmail.com 
traditionnelle de fromage fabriqué à partir de lait de yak. Trente-cinq lactobacilles isolés de cinq échantillons différents obtenus de différents endroits d'Arunachal Pradesh (Inde) ont été analysés à l'aide de méthodes phénotypiques et génotypiques. Le séquençage de l' $\mathrm{ADNr} 16 \mathrm{~S}$ de tous les isolats a été réalisé. Cinq espèces différentes de lactobacilles ont été isolées du fromage Churpi avec une prédominance de Lactobacillus paracasei suivi par Lactobacillus plantarum. Tous les isolats ont ensuite été évalués pour leurs propriétés technologiques telles que l'utilisation du citrate, la production d'exopolysaccharides (EPS), de bactériocine et d'acide. $43 \%$ des isolats se sont avérés positifs pour l'utilisation du citrate, $14 \%$ bons producteurs d'acide et $11 \%$ producteurs d'EPS. Lactobacillus coryniformis, espèce rare dans le fromage, a été trouvé dans le fromage Churpi. Les isolats obtenus dans la présente étude pourraient servir au développement de levains de souches définies pour la fabrication de fromage Churpi.

\section{fromage Churpi / Lactobacillus / ADNr 16S / lait de yak}

\section{INTRODUCTION}

Yak (Bos grunniens; now Poephagus grunniens) is one of a few domesticated animals capable of surviving in extreme environmental conditions. It is mainly found in the highlands of the Nepalese Himalayas, India (Kashmir and Arunachal Pradesh), China (Tibetan highlands), Mongolia, and Bhutan. The composition of yak milk is $16.9-17.7 \mathrm{~g} \cdot \mathrm{L}^{-1}$ dry matter, $49-53 \mathrm{~g} \cdot \mathrm{L}^{-1}$ protein, $55-72 \mathrm{~g} \cdot \mathrm{L}^{-1}$ fat, $45-50 \mathrm{~g} \cdot \mathrm{L}^{-1}$ lactose, and 8-9 $\mathrm{g} \cdot \mathrm{L}^{-1}$ minerals [20]. Yak milk is processed into a number of dairy products such as butter, fermented milk (e.g. Kurut), and cheese (e.g. Churpi). Churpi, the socalled in Tibetan and Nepali languages and byaslag in Mongolia, is a delicious cheese having a consistency ranging from soft to slightly hard, color white to orange, taste and odor, sour to pungent, $\mathrm{pH}$ 5.977.0. It is traditionally made from yak milk in an indigenous cylindrical churner made of wood and bamboo strips. Churpi cheese is an artisanal cheese manufactured from raw yak milk on a small scale and at a household level with the common practice of backslopping. Cheese blocks are brined and aged for 4-5 months at ambient temperature for the development of a good flavor. The chemical composition of yak cheese is around $68.2 \%$ of total solid (TS), $49.4 \%$ of butterfat on a dry matter basis, and $1.37 \%$ of salt [20]. It is largely consumed in the Himalayan highland and its industrial production is not yet standardized.

The biodiversity of commercial starters has become limited due to the large-scale use of starter culture for industrial fermentation process. Traditional dairy products have their natural microflora from non-pasteurized milk and raw materials are still the source of new strains [19]. Pure cultures isolated from complex ecosystems of traditionally fermented foods exhibit a diversity of metabolic activities that diverge strongly from the ones of comparable strains used as industrial bulk starters [11]. Thus, efforts should be made to preserve the microbial diversity of raw milk and traditional dairy products. Knowledge of the prevalence of lactic acid bacteria (LAB) in the natural flora of Churpi can pave the way for the formulation of defined strain starter. Microbial diversity has been studied using various DNA fingerprinting techniques like RAPD-PCR, RFLP, ribotyping, and DGGE. However, sequencing of $16 \mathrm{~S}$ rRNA gene is more reliable for molecular ecology and diversity analysis study because it is difficult to identify minor components of microbiota by other methods [10]. In the context of Churpi, no previous report concerning the genotypic and phenotypic characterization of the microflora has been found. Hence, this study was taken up with the objective of phenotypic, genotypic, and technological characterization of Lactobacillus isolated from Churpi cheese. 


\section{MATERIALS AND METHODS}

\subsection{Samples}

Five Churpi cheese samples were analyzed in this study, of which two were obtained from the National Research Centre for Yak (NRCY, Arunachal Pradesh) and three samples were procured from domestic sources and local markets of Arunachal Pradesh. All samples were collected aseptically in sterile NASCO sampling bags kept in an ice box and transported to the laboratory for analysis.

\subsection{Isolation of Lactobacillus}

Ten grams of cheese sample were homogenized with $90 \mathrm{~mL}$ of $2 \%$ trisodium citrate, serially diluted $\left(10^{-1}-10^{-8}\right)$ in saline solution, plated into DeMan, Rogosa and Sharpe (MRS) agar medium (Oxoid, Hampshire, England), and incubated under anaerobic conditions in $\mathrm{CO}_{2}$ incubator (New Brunswick Scientific Co., NJ, USA) at $37{ }^{\circ} \mathrm{C}$ for $48-72 \mathrm{~h}$. Twenty colonies were randomly picked from each plate and purified by streaking on MRS agar plates. A total of 200 colonies were screened on the basis of Gram reaction, morphology, and catalase test; 35 putative Lactobacillus isolates so obtained were further characterized by biochemical and molecular methods. The isolates were preserved by lyophilization (Edwards High Vacuum International, Sussex, England) and also as glycerol stocks (MRS broth with 30\% glycerol) at $-20{ }^{\circ} \mathrm{C}$ for further characterization.

\subsection{Reference strains}

The reference strains viz. Lactobacillus plantarum NCDC 221 (NCDO 340), Lactobacillus delbrueckii ssp. lactis NCDC 3 (ATCC 4797), Lactobacillus fermentum NCDC 155 (ATCC 8289),
Lactobacillus paracasei NCDC 63 (ATCC 393), Lactobacillus rhamnosus NCDC 24 (ATCC 8014), Lactobacillus helveticus NCDC 5 (ATCC 8018), and Lactobacillus brevis NCDC 337 (ATCC 14869) were obtained from the National Collection of Dairy Cultures (NCDC), National Dairy Research Institute, Karnal, Haryana, India.

\subsection{Phenotypic characterization of isolates}

Isolates were Gram-stained and tested for catalase activity. All isolates were tested for their ability to grow at 10, 15, and $45{ }^{\circ} \mathrm{C}$, at different concentrations of $\mathrm{NaCl}$ $(4 \%, 6.5 \%$, and $8 \%$ ), at $\mathrm{pH} 3.9$ and 9.6, and their ability to produce $\mathrm{CO}_{2}$ by the fermentation of glucose and $\mathrm{NH}_{3}$ production from arginine. Sugar fermentation patterns were determined using the CHL as basal medium.

\subsection{Microbiological analysis}

For enumerating LAB, $10 \mathrm{~g}$ of each cheese sample was dissolved in $90 \mathrm{~mL}$ of $2 \%$ sodium citrate buffer, which was serially diluted using physiological saline $\left(10^{-5}\right.$, $10^{-6}$, and $10^{-7}$ ). LAB were enumerated by pour plating the dilutions on lactic agar (Oxoid, Hampshire, England) and incubating for $72 \mathrm{~h}$ at $37^{\circ} \mathrm{C}$.

\subsection{Genotypic characterization of Lactobacillus}

Genomic DNA was extracted from $2 \mathrm{~mL}$ samples of overnight cultures grown in MRS broth at $37{ }^{\circ} \mathrm{C}$ as previously described [13]. Lactobacillus genus-specific primer (Tab. I) targeting 16S rRNA gene was used for the confirmation of Lactobacillus genus as previously described [7]. Polymerase chain reaction (PCR) was performed for the identification of isolates in $25 \mu \mathrm{L}$ of reaction volume, containing 50-100 ng 
Table I. List of primers used in this study for Lactobacillus identification.

\begin{tabular}{|c|c|c|c|c|c|}
\hline Target & Primer & Primer sequence $5^{\prime}-3^{\prime}$ & $\mathrm{Ta}\left({ }^{\circ} \mathrm{C}\right)$ & Product size $(\mathrm{bp})$ & Reference \\
\hline Lactobacillus genus & $\begin{array}{l}\text { Genus-F } \\
\text { Genus-R }\end{array}$ & $\begin{array}{l}\text { CTCAAAACTAAACAAAGTTTC } \\
\text { CTTGTACACACCGCCCGTCA }\end{array}$ & 55 & 250 & [7] \\
\hline $\begin{array}{l}\text { 7F } \\
\text { S-G-Lab-0677-R }\end{array}$ & $\begin{array}{c}7 F \\
\text { S-G-Lab-0677-R }\end{array}$ & $\begin{array}{l}\text { AGAGTTTGAT(C/T)(A/C)TGGCTCAG } \\
\text { CACCGCTACACATGGAG }\end{array}$ & 57 & 700 & {$[8,12]$} \\
\hline L. casei & $\begin{array}{l}\mathrm{Y} 1 \\
\text { L. casei }\end{array}$ & $\begin{array}{l}\text { TGGCTCAGAACGAACGCTAGGCCCG } \\
\text { TGCACTGAGATTCGACTTAA }\end{array}$ & 52 & 290 & {$[19,23]$} \\
\hline L. paracasei & $\begin{array}{c}\mathrm{Y} 1 \\
\text { L. paracasei }\end{array}$ & $\begin{array}{l}\text { TGGCTCAGAACGAACGCTAGGCCCG } \\
\text { CACCGAGATTCAACATGG }\end{array}$ & 52 & 290 & {$[18,22]$} \\
\hline L. pentosus & $\begin{array}{l}16 \\
\text { L. pentosus }\end{array}$ & $\begin{array}{l}\text { GCTGGATCACCTCCTTTC } \\
\text { GTATTCAACTTATTAGAACG }\end{array}$ & 53 & 220 & [5] \\
\hline L. plantarum & $\begin{array}{l}16 \\
\text { L. plantarum }\end{array}$ & $\begin{array}{l}\text { GCTGGATCACCTCCTTTC } \\
\text { ATGAGGTATTCAACTTATG }\end{array}$ & 53 & 220 & [5] \\
\hline prtP & $\begin{array}{l}\text { P6 } \\
\text { P7 }\end{array}$ & $\begin{array}{l}\text { CAACACGGCATGCATGTTGC } \\
\text { CTGGCGTTCCCACCATTCA }\end{array}$ & 55 & 393 & [11] \\
\hline
\end{tabular}


of genomic DNA, $1 \mathrm{X}$ Taq buffer, $1.5 \mathrm{mmol} \cdot \mathrm{L}^{-1} \mathrm{MgCl}_{2}, 10 \mathrm{mmol} \cdot \mathrm{L}^{-1}$ of each dNTP, $50 \mathrm{ng}$ of each primer, and 1 unit of Taq DNA polymerase (Bangalore Genei, Bangalore, India). Amplification was performed on an Eppendorf Mastercycler (Hamburg, Germany) according to earlier published literature $[5,7,8,11,12,18,22]$. Amplification was verified by electrophoresis on $1.5 \%(\mathrm{w} / \mathrm{v})$ agarose gel in $1 \mathrm{X}$ TAE buffer using a $100 \mathrm{bp}$ ladder (Bangalore Genei, Bangalore, India) as a molecular weight marker. Gels were stained with ethidium bromide $\left(1 \mathrm{mg} \cdot \mathrm{mL}^{-1}\right)$.

Sequencing of $16 \mathrm{~S}$ rDNA and phylogenetic analysis were performed as follows.

16S rDNA gene of all 35 isolates was amplified using primer 7F [12] and primer S-G-Lab-0677-R (Tab. I) [8]. The amplified PCR products from 35 isolates were purified with sodium acetate-ethanol precipitation. The PCR products $(10 \mu \mathrm{L})$ were directly sequenced using primer $7 \mathrm{~F}$ [12] with the help of Big Dye Terminator Cycle Sequencing Kit (Applied Biosystem, Foster City, USA) on an automated genetic analyzer (ABI 3100 Applied Biosystem, USA) to obtain partial sequence of the $16 \mathrm{~S}$ rDNA. Sequences so obtained were analyzed using the Chromas software (version 1.45, http://www.technelysium. com.au/chromas.html). BLAST analysis was performed to check the identity of DNA sequence in the database and for species determination.

For the differentiation of closely related species, Lactobacillus casei and L. paracasei, Lactobacillus pentosus and L. plantarum, species-specific PCR [5, 18] was performed (Tab. I).

\subsection{Technological characterization of isolates}

The isolates were evaluated in triplicates for various technological attributes.

In order to determine the lactic acidproducing ability of all isolates, tubes containing $20 \mathrm{~mL}$ of heat-treated $\left(90{ }^{\circ} \mathrm{C}\right.$, $10 \mathrm{~min}$ ) reconstituted skimmed milk (Modern Dairies, Karnal, India) having 11.5\% TS were inoculated with active culture $(1 \% \mathrm{v} / \mathrm{v})$ and incubated at $37{ }^{\circ} \mathrm{C}$ for 6 and $24 \mathrm{~h}$. The percentage of lactic acid was estimated of samples by titrating curd with $0.1 \mathrm{~N} \mathrm{NaOH}$ to an end point of pale pink using phenolphthalein as indicator and the $\mathrm{pH}$ of acidified milk was measured using a $\mathrm{pH}$ meter (Thermo Electron, Madison, WI, USA) in triplicate.

Exopolysaccharide (EPS) production of Lactobacillus isolates was screened by copper sulfate staining [1]. The isolates were microscopically examined for capsule formation.

Citrate utilization by Lactobacillus isolates was screened qualitatively on modified differential agar medium in which the formation of Prussian blue colonies shows positive citrate fermenting colonies as previously described [9].

To screen isolates for bacteriocin production, an assay was performed against two indicator organisms, Pediococcus acidilacticis NCDC 252 and L. brevis NCDC 01, using agar well diffusion assay [4].

All isolates were examined for the presence of the prtP gene coding for cell envelope proteinase. In order to amplify this gene, primers P6 and P7 (Tab. I) were used according to PCR conditions previously described [11].

\section{RESULTS}

Mesophilic lactic count of cheese samples was found to vary between $6.1 \times 10^{6}$ and $7.1 \times 10^{6} \mathrm{~g}^{-1}$. Of 200 colonies initially screened on the basis of microscopic examination and catalase test, 35 isolates appeared to belong to the Lactobacillus genus and were further characterized by biochemical and molecular methods. All 35 isolates conformed to the general phenotypic characteristics of genus Lactobacillus, 
Table II. Biochemical and technological characteristics of Lactobacillus strains isolated from Churpi cheese (Fig. 2).

\begin{tabular}{|c|c|c|c|c|c|c|c|c|c|c|c|c|c|c|c|c|}
\hline \multirow[t]{2}{*}{ Isolates } & \multicolumn{8}{|c|}{ Growth at } & \multirow{2}{*}{ Arginine } & \multirow{2}{*}{$\begin{array}{c}\text { Citrate } \\
\text { utilization }\end{array}$} & \multirow{2}{*}{ prtP gene } & \multirow{2}{*}{\multicolumn{2}{|c|}{ EPS $p H 6 h^{a}$}} & \multirow{2}{*}{$\mathrm{pH} 24 \mathrm{~h}^{\mathrm{a}}$} & \multirow{2}{*}{$\begin{array}{l}\text { Acidity } \\
6 \mathrm{~h}^{\mathrm{a}}\end{array}$} & \multirow{2}{*}{$\begin{array}{l}\text { Acidity } \\
24 \mathrm{~h}^{\mathrm{a}}\end{array}$} \\
\hline & $\begin{array}{c}4 \% \\
\mathrm{NaCl}\end{array}$ & $\begin{array}{l}6.5 \% \\
\mathrm{NaCl} \\
\end{array}$ & $\begin{array}{c}8 \% \\
\mathrm{NaCl}\end{array}$ & pH 3. & H 9.6 & $10^{\circ} \mathrm{C}$ & $15^{\circ}$ & $15^{\circ} \mathrm{C}$ & & & & & & & & \\
\hline L. brevis $\mathrm{Y}-1-3$ & - & - & - & - & - & - & + & - & + & + & - & - & 4.34 & 4.13 & 0.90 & 1.17 \\
\hline L. brevis $\mathrm{Y}-2-10$ & + & - & - & + & - & - & + & - & + & + & - & - & 4.26 & 4.03 & 0.85 & 1.05 \\
\hline L. coryniformis Y-1-17 & + & - & - & - & - & + & + & + & - & - & - & - & 6.56 & 5.33 & 0.20 & 0.46 \\
\hline L. coryniformis Y-1-18 & - & - & - & - & - & + & + & - & - & - & - & - & 6.56 & 5.23 & 0.24 & 0.45 \\
\hline L. coryniformis Y-3-1 & - & - & - & - & - & + & + & - & - & - & - & - & 6.44 & 5.41 & 0.38 & 0.42 \\
\hline L. coryniformis Y-3-8 & + & - & - & - & - & + & + & - & - & - & - & - & 6.46 & 4.17 & 0.94 & 1.01 \\
\hline L. paracasei $\mathrm{Y}-1-10$ & + & - & - & - & - & - & + & - & - & + & + & - & 5.71 & 5.14 & 0.45 & 0.55 \\
\hline L. paracasei $\mathrm{Y}-1-19$ & + & + & - & - & - & - & + & - & - & - & + & - & 6.39 & 5.0 & 0.24 & 0.43 \\
\hline L. paracasei $\mathrm{Y}-1-20$ & + & - & - & - & - & - & + & - & - & + & + & - & 6.36 & 5.24 & 0.25 & 0.50 \\
\hline L. paracasei $\mathrm{Y}-1-23$ & + & - & - & - & - & - & + & - & - & - & + & - & 6.37 & 4.84 & 0.30 & 0.70 \\
\hline L. paracasei $\mathrm{Y}-3-2$ & + & + & - & - & - & + & + & - & - & + & - & - & 5.55 & 5.40 & 0.24 & 0.46 \\
\hline L. paracasei $\mathrm{Y}-3-5$ & + & - & - & - & - & + & + & - & - & - & + & - & 4.30 & 4.10 & 0.87 & 0.97 \\
\hline L. paracasei $\mathrm{Y}-3-6$ & - & - & - & - & - & + & + & - & - & - & + & - & 6.52 & 5.30 & 0.23 & 0.5 \\
\hline L. paracasei $\mathrm{Y}-3-10$ & - & - & - & - & - & + & + & - & - & - & + & - & 6.39 & 4.44 & 0.23 & 0.97 \\
\hline L. paracasei Y-3-11 & - & - & - & - & - & + & + & - & - & - & - & - & 4.25 & 4.01 & 0.23 & 1.01 \\
\hline L. paracasei NRC-1 & - & - & - & - & - & + & + & - & - & + & + & - & 5.70 & 5.43 & 0.26 & 0.42 \\
\hline L. paracasei $\mathrm{NRC}-2$ & - & + & - & - & - & + & + & - & - & - & - & - & 5.98 & 5.02 & 0.35 & 0.67 \\
\hline L. paracasei $\mathrm{NRC}-3$ & + & + & - & - & - & + & + & - & - & + & - & - & 6.47 & 4.76 & 0.23 & 0.67 \\
\hline
\end{tabular}


Table II. Continued.

\begin{tabular}{|c|c|c|c|c|c|c|c|c|c|c|c|c|c|c|c|c|}
\hline \multirow[t]{2}{*}{ Isolates } & \multicolumn{8}{|c|}{ Growth at } & \multirow{2}{*}{ Arginine } & \multirow{2}{*}{$\begin{array}{c}\text { Citrate } \\
\text { utilization }\end{array}$} & \multirow{2}{*}{ prtP gene } & \multirow[t]{2}{*}{ EPS } & \multirow[t]{2}{*}{$\mathrm{pH} 6 \mathrm{~h}^{\mathrm{a}}$} & \multirow[t]{2}{*}{$\mathrm{pH} 24 \mathrm{~h}^{\mathrm{a}}$} & \multirow{2}{*}{$\begin{array}{c}\text { Acidity } \\
6 \mathrm{~h}^{\mathrm{a}}\end{array}$} & \multirow{2}{*}{$\begin{array}{l}\text { Acidity } \\
24 \mathrm{~h}^{\mathrm{a}}\end{array}$} \\
\hline & $\begin{array}{c}4 \% \\
\mathrm{NaCl}\end{array}$ & $\begin{array}{r}6.5 \% \\
\mathrm{NaCl}\end{array}$ & $\begin{array}{c}8 \% \\
\mathrm{NaCl}\end{array}$ & $\mathrm{pH} 3$. & pH 9.6 & $10^{\circ} \mathrm{C}$ & $15^{\circ} \mathrm{C}$ & $15^{\circ} \mathrm{C}$ & & & & & & & & \\
\hline L. paracasei NRC-4 & + & - & - & - & - & + & + & - & - & - & - & + & 5.07 & 4.90 & 0.72 & 0.87 \\
\hline L. paracasei NRC-5 & + & - & - & - & - & + & + & - & - & + & + & - & 4.44 & 4.20 & 0.93 & 1.07 \\
\hline L. paracasei NRC-6 & - & - & - & - & - & + & + & - & - & - & + & - & 5.56 & 5.21 & 0.62 & 0.53 \\
\hline L. paracasei NRC-7 & - & - & - & - & - & + & + & - & - & - & + & - & 5.74 & 5.13 & 0.31 & 0.64 \\
\hline L. paracasei NRC-11 & - & - & - & - & - & + & + & - & - & - & + & + & 5.20 & 5.14 & 0.54 & 0.60 \\
\hline L. plantarum Y-2-1 & + & - & - & - & - & - & + & - & - & + & - & - & 5.41 & 5.12 & 0.43 & 0.65 \\
\hline L. plantarum Y-2-5 & + & + & - & - & - & - & + & - & - & - & - & + & 5.63 & 5.17 & 0.46 & 0.56 \\
\hline L. plantarum Y-2-7 & + & - & - & - & - & - & + & - & - & - & - & - & 6.44 & 5.36 & 0.22 & 0.44 \\
\hline L. plantarum $\mathrm{Y}-2-8$ & + & + & - & - & - & - & + & - & - & + & - & - & 6.46 & 5.26 & 0.22 & 0.54 \\
\hline L. plantarum Y-2-9 & + & + & - & - & - & - & + & - & - & + & - & - & 6.45 & 5.94 & 0.22 & 0.42 \\
\hline L. plantarum Y-2-11 & + & + & - & - & - & - & + & - & - & + & - & - & 6.51 & 5.44 & 0.22 & 0.46 \\
\hline L. plantarum Y-2-14 & + & + & + & - & - & + & + & - & - & - & - & - & 4.99 & 4.32 & 0.83 & 0.96 \\
\hline L. plantarum Y-2-15 & + & - & - & - & - & - & + & - & - & + & - & - & 6.43 & 5.40 & 0.22 & 0.50 \\
\hline L. plantarum Y-2-16 & + & - & - & - & - & + & + & - & - & + & - & - & 6.47 & 5.37 & 0.22 & 0.43 \\
\hline L. plantarum Y-2-17 & + & + & - & - & - & - & + & - & - & - & - & - & 6.53 & 5.28 & 0.22 & 0.54 \\
\hline L. plantarum Y-3-3 & + & - & - & - & - & + & + & - & - & + & - & + & 4.25 & 4.03 & 0.45 & 0.59 \\
\hline L. helveticus NRC-12 & - & - & - & - & - & - & + & - & - & - & - & - & 5.42 & 5.05 & 0.43 & 0.75 \\
\hline
\end{tabular}

${ }^{\text {a }}$ Mean value of triplicate. 


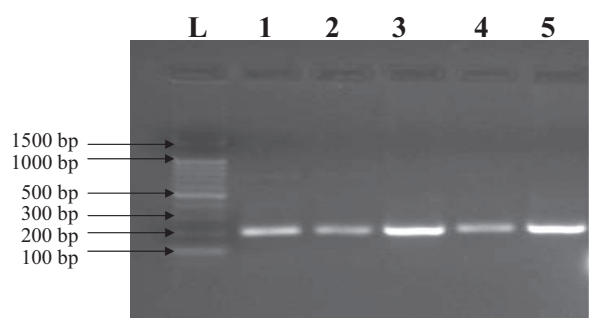

Figure 1. Genus-specific PCR of Lactobacillus $(250 \mathrm{bp}) \mathrm{L}=100 \mathrm{bp}$ ladder, lane $1=L$. brevis $\mathrm{Y}-1-3,2=L$. paracasei $\mathrm{Y}-1-10,3=L$. coryniformis $\mathrm{Y}-1-17,4=L$. plantarum $\mathrm{Y}-2-1$, and $5=L$. helveticus $\mathrm{NRC}-12$.

i.e. Gram positive, rod shaped, nonmotile, non-sporulating, and catalase negative (Tab. II). The generic status was further confirmed by PCR as all the isolates showed amplification product of expected size (250 bp) using genus-specific primers (Fig. 1). Based on the phenotypic characters, the isolates were tentatively designated as L. casei (17), L. plantarum (11), Lactobacillus coryniformis (4), L. brevis (2), and L. helveticus (1). For species confirmation, partial sequencing of $16 \mathrm{~S}$ rDNA (V1-V3 region) was performed. The species level identification could only be done for L. brevis, L. helveticus, and L. coryniformis isolates on the basis of $16 \mathrm{~S}$ rDNA sequencing. The species designation of other isolates could not be resolved by the 16S rDNA sequencing as the BLAST analysis results showed equal resemblance to the closely related species, L. casei and L. paracasei; L. plantarum and L. pentosus. To resolve the issue further, a species-specific PCR was performed and it finally confirmed the isolates to be $L$. paracasei and L. plantarum. Sequence data generated for all isolates were submitted to the GenBank under the following Accession Nos. EU637371EU637403, EU886737, and EU886738. Except the two isolates NRC-1 and NRC-2, the partial sequencing of 16S rDNA demonstrated high identity (99-100\%) with $16 \mathrm{~S}$ rDNA sequence respective to the members of Lactobacillus from the GenBank database.

\section{DISCUSSION}

The fermentation of traditional foods is usually affected by natural, wild-type LAB originating from the raw materials and the environment. This study shows the predominance of $L$. paracasei and $L$. plantarum in Churpi cheese. This cheese is made from raw milk of yak in indigenously designed churners made from wood and bamboo strips. The churners and the bamboo strips may contribute to the microflora of cheese as young bamboo shoots have been shown to harbor lactobacilli. Tamang and Sarkar [16] showed the predominance of L. plantarum and L. brevis in young bamboo shoots. In a recent study on fresh and fermented yak milk, Wu et al. [21] reported the presence of L. fermentum, L. helveticus, and Lactobacillus curvatus showing that lactobacilli could play an important role in the fermentation of yak milk.

L. paracasei, L. brevis, and L. plantarum have been reported to be the predominant members of the nonstarter lactic acid bacteria (NSLAB) community of mature Zlatar and Spanish goat cheese [14, 17], which are also artisanal type of cheese. The lactobacilli grow as secondary flora particularly during the maturation process and influence the organoleptic properties of the cheese [17]. Lactobacillus species, viz. L. brevis, L. fermentum, L. rhamnosus, and L. coryniformis, are less commonly found in cheese where NSLAB densities are initially lower and build up with time during maturation [6]. L. coryniformis is an uncommon species found in low densities in cheeses and we obtained the same result in the case of Churpi cheese also. In this study, we tried to identify the isolates genotypically by comparing the partial sequence of $16 \mathrm{~S}$ rDNA as the majority of lactobacilli can be identified by sequencing of the first half region, i.e. from $\mathrm{V} 1$ to $\mathrm{V} 3$ 


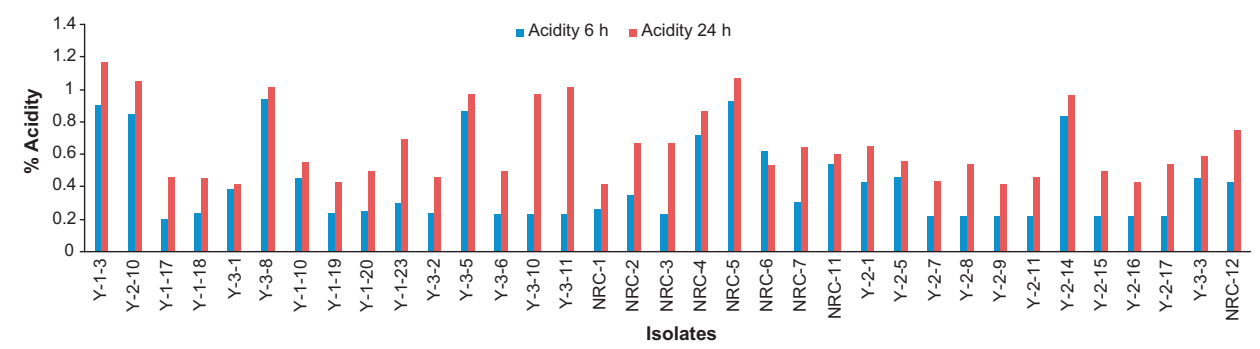

Figure 2. Percentage acidity (mean value of triplicate) produced after 6 and $24 \mathrm{~h}$ by different isolates of Lactobacillus as listed in Table II.

of $16 \mathrm{~S}$ rDNA [3]. However, it was not able to resolve some of the closely related species, as L. casei, L. paracasei, L. plantarum, and $L$. pentosus showed a very high degree of sequence similarity in the amplified region. In such cases, the use of speciesspecific PCR or complete sequencing of $16 \mathrm{~S}$ rDNA is preferable [15]. The identity of closely related species was successfully ascertained by the use of species-specific PCR. Genotypic heterogeneity could be seen in $L$. paracasei as isolates NRC-1 and NRC-2 showed only $95-96 \%$ sequence similarity, with the existing sequences in the GenBank database.

Technological properties of starter and nonstarter bacteria are known to affect the cheese quality. The most acidifying strains found were L. coryniformis (Y-3-8), L. paracasei (NRC-5), L. brevis (Y-1-3), L. paracasei (Y-3-5), L. brevis (Y-2-10), and L. plantarum (Y-2-14), which produced between $0.83 \%$ and $0.94 \%$ lactic acid after $6 \mathrm{~h}$ at $37^{\circ} \mathrm{C}$, while other isolates produced lower amounts of lactic acid in milk. Among strains of different LAB isolated from traditional Egyptian dairy products, Ayad et al. [2] also reported overall lower acidifying activity in the case of wild-type lactococci. A total of 15 citrate utilizing isolates were identified belonging to L. plantarum and L. paracasei. Crow et al. [6] also reported NSLAB from Cheddar cheese to be citrate fermenters. The citrate-positive isolates can influence the organoleptic attributes of cheese due to the production of carbonyl compounds and carbon dioxide. The production of EPS influences the textural and rheological properties of fermented milk products. It contributes to water retention in the final product, may impart a higher flavor intensity due to carbohydrate masking, and improve the mouth feel. The proteolytic activity of LAB has a role in cheese maturation. In this study, only L. paracasei isolates (12) were found positive for the prtP gene. As all technological properties were estimated only qualitatively, hence no relationship could be established among different technological traits.

A polyphasic approach involving the combination of biochemical and molecular techniques allowed the identification of lactobacilli in Churpi cheese. No discrepancy was detected in phenotypic traits and molecular identification. These strains of lactobacilli can be further explored for the development of primary and adjunct starter cultures for Churpi and other artisanal cheeses.

Acknowledgments: We sincerely acknowledge the financial assistance of the Indian Council of Agriculture Research (ICAR), Government of India, New Delhi in the form of Network Project on Application of Microbes in Agriculture and Allied Sectors (AMAAS). The authors also acknowledge the help provided by the Directors of NBAIM and NBAGR. Senior Research Fellowship of Prashant by ICAR is also acknowledged. 


\section{REFERENCES}

[1] Anthony E.E., A note on capsule staining, Science 73 (1931) 319.

[2] Ayad E.H.E., Verheul A., de Jong C., Wouters J.T.M., Smit G., Flavour forming abilities and amino acid requirements of Lactococcus lactis strains isolated from artisanal and non-dairy origin, Int. Dairy J. 9 (1999) 725-735.

[3] Balcazar J.L., de Blas I., Ruiz-Zarzuela I., Vendrell D., Girones O., Muzquiz J.L., Sequencing of variable regions of the 16S rRNA gene for identification of lactic acid bacteria isolated from the intestinal microbiota of healthy salmonids, Comp. Immunol. Microbiol. Infect. Dis. 30 (2007) 111-118.

[4] Barefoot S.F., Klaenhammer T.R., Detection and activity of lactacin $\mathrm{B}$, a bacteriocin produced by Lactobacillus acidophilus, Appl. Environ. Microbiol. 45 (1983) 1808-1815.

[5] Berthier F., Ehrlich S.D., Rapid species identification within two groups of closely related lactobacilli using PCR primers that target the $16 \mathrm{~S} / 23 \mathrm{~S}$ rRNA spacer region, FEMS Microbiol. Lett. 161 (2006) 97-106.

[6] Crow V., Curry B., Hayes M., The ecology of non-starter lactic acid bacteria (NSLAB) and their use as adjuncts in New Zealand Cheddar, Int. Dairy J. 11 (2001) 275-283.

[7] Dubernet S., Desmasures N., Gueguen M., A PCR-based method for identification of lactobacilli at the genus level, FEMS Microbiol. Lett. 214 (2002) 271-275.

[8] Heilig G.H.J., Zoetendal E.G., Marteau E.E., Akkermans A.D.L., de Vos W.M., Molecular diversity of Lactobacillus spp. and other lactic acid bacteria in the human intestine as determined by specific amplification of $16 \mathrm{~S}$ ribosomal DNA, Appl. Environ. Microbiol. 68 (2002) 114-123.

[9] Kempler G.M., McKay L.L., Improved medium for detection of citrate-fermenting Streptococcus lactis subsp. diacetylactis, Appl. Environ. Microbiol. 39 (1980) 926-927.

[10] Kim M., Chun J., Bacterial community structure in kimchi, a Korean fermented vegetable food, as revealed by $16 \mathrm{~S}$ rRNA gene analysis, Int. J. Food Microbiol. 103 (2005) 91-96.

[11] Klijn N., Weerkamp A.H., de Vos W.M., Detection and characterization of lactoseutilizing Lactococcus subsp. in natural ecosystems, Appl. Environ. Microbiol. 61 (1995) 788-792.

[12] Lane D.J., 16S/23S rRNA sequencing, in: Stackebrandt E.R., Goodfellow M. (Eds.), Nucleic Acid Techniques in Bacterial Systematic, John Wiley \& Sons Ltd., Chichester, UK, 1991, pp. 115-175.

[13] Pospiech A., Neumann B., A versatile quickprep of genomic DNA from Gram-positive bacteria, Trends Genet. 11 (1995) 217-218.

[14] Sancheza I., Sesenab S., Povedaa J.M., Cabezasa L., Palopb L., Phenotypic and genotypic characterization of lactobacilli isolated from Spanish goat cheeses, Int. J. Food Microbiol. 102 (2005) 355-362.

[15] Stackebrandt E., Goebel B.M., Taxonomic note: a place for DNA-DNA reassociation and $16 \mathrm{~S}$ rRNA sequence analysis in the present species definition in bacteriology, Int. J. Syst. Bacteriol. 44 (1994) 846-849.

[16] Tamang J.P., Sarkar P.K., Microbiology of mesu, a traditional fermented bamboo shoot product, Int. J. Food Microbiol. 29 (1996) 49-58.

[17] Veljovic K., Terzic-Vidojevic A., Vukasinovic M., Strahinic I., Begovic J., Lozo J., Ostojic M., Topisirovic L., Preliminary characterization of lactic acid bacteria isolated from Zlatar cheese, J. Appl. Microbiol. 103 (2007) 2142-2152.

[18] Ward L.J.H., Timmins M.J., Differentiation of Lactobacillus casei, Lactobacillus paracasei and Lactobacillus rhamnosus by polymerase chain reaction, Lett. Appl. Microbiol. 29 (1999) 90-92.

[19] Weerkamp A.H., Klijn N., Neeter R., Smit G., Properties of mesophilic lactic acid bacteria from raw milk and naturally fermented raw milk products, Neth. Milk Dairy J. 50 (1996) 319-332.

[20] Wiener G.H., Jianlin H., Ruijun L., Production characteristics of yak, in: The Yak, 2nd Edn., RAP Publication, FAO Regional Office for Asia and the Pacific, Bangkok, Thailand, 2003, pp. 119-171.

[21] Wu X.H., Luo Z., Yu L., Ren F.-Z., Han B.-Z., Nout M.J.R., A survey on composition and microbiota of fresh and fermented yak milk at different Tibetan altitudes, Dairy Sci. Technol. 89 (2009) 201-209.

[22] Young J.P.W., Downer H.L., Eardly B.D., Phylogency of the phototrophic Rhizobium strain BTAil by polymerase chain reactionbased sequencing of a 16S rRNA gene segment, J. Bacteriol. 173 (1991) 2271-2277. 